\title{
Quadratus lumborum block type 2 for pedicle groin flap analgesia: a case report
}

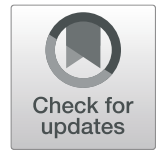

Tatsunori Watanabe ${ }^{1^{*}}$, Koji Moriya ${ }^{2}$ and Hiroshi Baba ${ }^{3}$

Keywords: Quadratus lumborum block type 2, Pedicle groin flap, Postoperative analgesia

To the Editor,

Quadratus lumborum block type 2 (QLB2) is used to provide lateral and lower abdominal sensory block [1]. Herein, we describe a case involving the use of QLB2 for analgesia of a pedicle groin flap. Patient consent was obtained for publication of this report. The patient was a 51-year-old man (height, $168 \mathrm{~cm}$; weight, $65 \mathrm{~kg}$ ) who had his left hand crushed in an industrial press machine more than a month prior to the current presentation. Replantation of the middle and ring fingers was performed 1 month prior; however, these fingers became necrotic. Therefore, he was scheduled for a left pedicle flap procedure to address the necrosis. His medical history was unremarkable.

With standard monitoring and no premedication, general anesthesia was induced with propofol (100 $\mathrm{mg})$, remifentanil $(0.25 \mu \mathrm{g} / \mathrm{kg} / \mathrm{min})$, and rocuronium $(20 \mathrm{mg})$. After insertion of the \#4 laryngeal mask airway, general anesthesia was maintained with sevoflurane $(1.5 \%)$ and remifentanil $(0.1 \mu \mathrm{g} / \mathrm{kg} / \mathrm{min})\left(\mathrm{FiO}_{2}: 0.4\right)$. A left supraclavicular brachial plexus block followed by QLB2 were performed under ultrasound guidance using $30 \mathrm{~mL}$ of $0.25 \%$ ropivacaine, respectively (total, $150 \mathrm{mg}$ ropivacaine). For the QLB2 procedure, a linear transducer was placed in the axial plane in the midaxillary line and moved posteriorly until the quadratus lumborum was confirmed. The target was posterior to the quadratus lumborum, and the needle tip was advanced near the lumbar interfascial triangle. Local injections were administered between the area posterior

\footnotetext{
* Correspondence: tatsu-w@med.niigata-u.ac.jp

'Division of Anesthesiology, Uonuma Institute of Community Medicine, Niigata University Medical and Dental Hospital, 4132 Urasa, Minami-Uonuma, Niigata 949-7302, Japan

Full list of author information is available at the end of the article
}

to the quadratus lumborum and outside the middle layer of the thoracolumbar fascia.

The surgical procedure included debridement of the hand, followed by the creation of a pedicle groin flap at the left inguinal region (Fig. 1). No increases in blood pressure or heart rate were noted during surgery. At the end of the surgery, infusion of anesthetics was discontinued, sugammadex ( $200 \mathrm{mg}$ ) was administered, and the laryngeal mask airway was removed. The patient reported only pre-existing shoulder pain but no wound pain (numerical rating scale 0/10) even though no additional analgesics were administered postoperatively. On postoperative day 1 , he received loxoprofen $(60 \mathrm{mg})$ three times. He subsequently reported a wound pain (on a numerical rating scale) of $1 / 10$ at rest and $3 / 10$ while in motion. Three weeks later, the second surgery to divide the pedicle was performed under local infiltration anesthesia.

QLB2 and brachial plexus nerve block provided good postoperative analgesia in the present case, and there was evidently no need for opioids. QLB2 has been previously reported for analgesia in the T10$\mathrm{T} 12$ or L1 in the cranial-caudal direction and in the area around the posterior axillary line on the dorsal side and over the linea semilunaris on the ventral side [1]. Although it is unknown whether QLB2 contributed to anesthesia during the creation of the pedicle groin flap, it was demonstrably effective for postoperative analgesia at the site.

Notably, a single block has been previously reported to provide sufficient effects during soft tissue surgery [2]. Similarly, a single dose provided sufficient effects in the current case.

\section{Springer Open}

(-) The Author(s). 2020 Open Access This article is licensed under a Creative Commons Attribution 4.0 International License which permits use, sharing, adaptation, distribution and reproduction in any medium or format, as long as you give appropriate credit to the original author(s) and the source, provide a link to the Creative Commons licence, and indicate if changes were made. The images or other third party material in this article are included in the article's Creative Commons licence, unless indicated otherwise in a credit line to the material. If material is not included in the article's Creative Commons licence and your intended use is not permitted by statutory regulation or exceeds the permitted use, you will need to obtain permission directly from the copyright holder. To view a copy of this licence, visit http://creativecommons.org/licenses/by/4.0/. 

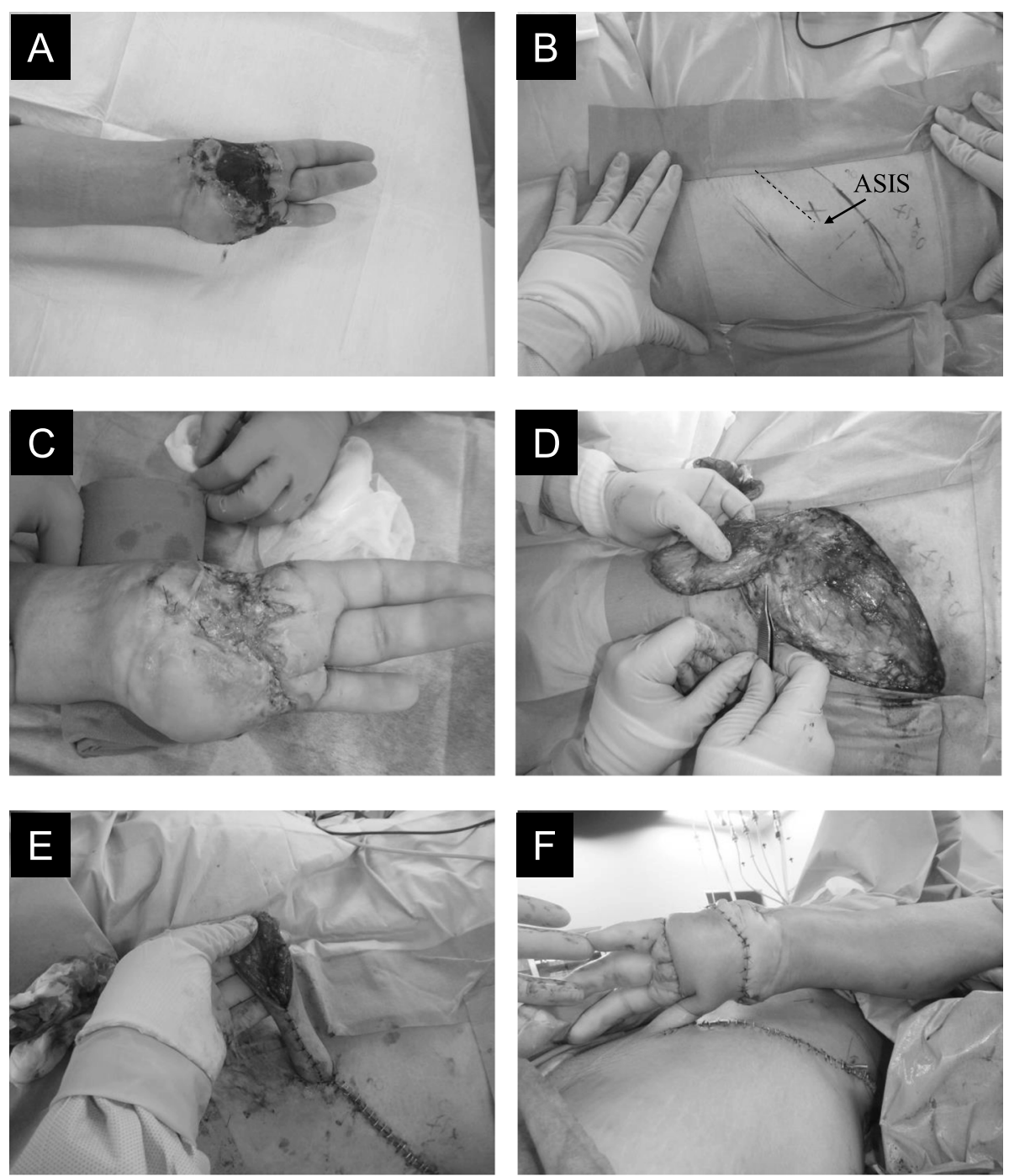

Fig. 1 a Injured left hand with necrosis. Both the thumb and the index finger were missing. $\mathbf{b}$ The donor site of the pedicle groin flap in the left inguinal region. The dotted line between the anterior superior iliac spine (ASIS) and the femoral artery $2-2.5 \mathrm{~cm}$ below the inguinal ligament is drawn (axial line of the flap). c Debridement of the left hand. $\mathbf{d}$ Construction of the flap. e Tubed pedicle. $\mathbf{f}$ The flap sutured in position

\section{Abbreviations}

QLB2: Quadratus lumborum block type 2; ASIS: Anterior superior iliac spine

\section{Acknowledgements}

The authors would like to thank Editage ${ }^{\oplus}$ for the English language review.

\section{Authors' contributions}

T.W and K.M helped care for the patient. T.W drafted the article, while the other authors revised the article critically for important intellectual content. All authors approved the final version to be published.

\section{Funding}

The authors received no financial support for publication of this article.

\section{Availability of data and materials}

Please contact author for data requests.

\section{Ethics approval and consent to participate}

We had obtained comprehensive consent beforehand from the patient, and we confirmed agreement to report clinical experience from the patient. In our institution, case reports are exempted from Ethics Committee approval.

\section{Consent for publication}

Written consent for publication was obtained from the patient.

\section{Competing interests}

The authors declare that they have no competing interests.

\section{Author details}

'Division of Anesthesiology, Uonuma Institute of Community Medicine, Niigata University Medical and Dental Hospital, 4132 Urasa, Minami-Uonuma, Niigata 949-7302, Japan. ${ }^{2}$ Niigata Hand Surgery Foundation, Niigata, Japan. ${ }^{3}$ Division of Anesthesiology, Niigata University Graduate School of Medical and Dental Sciences, Niigata, Japan.

Received: 27 April 2020 Accepted: 7 May 2020

Published online: 17 May 2020

\section{References}

1. Tamura T, Yokota S, Ito S, Shibata Y, Nishiwaki K. Local anesthetic spread into the paravertebral space with two types of quadratus lumborum blocks: a crossover volunteer study. J Anesth. 2019;33:26-32. 
2. Watanabe T, Moriya K, Yoda T, Tsubokawa N, Petrenko AB, Baba H. Risk factors for rescue analgesic use on the first postoperative day after upper limb surgery performed under single-injection brachial plexus block: a retrospective study of 930 cases. JA Clin Rep. 2017;3:39.

\section{Publisher's Note}

Springer Nature remains neutral with regard to jurisdictional claims in published maps and institutional affiliations.

\section{Submit your manuscript to a SpringerOpen ${ }^{\odot}$ journal and benefit from:}

- Convenient online submission

- Rigorous peer review

- Open access: articles freely available online

- High visibility within the field

- Retaining the copyright to your article

Submit your next manuscript at $\boldsymbol{\wedge}$ springeropen.com 